\title{
MIDAS
}

Museus e estudos interdisciplinares

\section{Jean-Paul Martinon, ed. - The Curatorial: A Philosophy of Curating}

\section{Sofia Romualdo}

\section{(2) OpenEdition}

\section{Journals}

Electronic version

URL: http://journals.openedition.org/midas/924

DOI: $10.4000 /$ midas.924

ISSN: 2182-9543

\section{Publisher:}

Alice Semedo, Paulo Simões Rodrigues, Pedro Casaleiro, Raquel Henriques da Silva, Ana Carvalho

\section{Electronic reference}

Sofia Romualdo, « Jean-Paul Martinon, ed. - The Curatorial: A Philosophy of Curating », MIDAS [Online], 5 | 2015, Online since 03 December 2015, connection on 22 September 2020. URL : http://

journals.openedition.org/midas/924; DOI : https://doi.org/10.4000/midas.924

This text was automatically generated on 22 September 2020 .

\section{cc) (†)}

Midas is licensed under a Creative Commons Attribution-NonCommercial-ShareAlike 3.0 International License 


\title{
Jean-Paul Martinon, ed. - The Curatorial: A Philosophy of Curating
}

\author{
Sofia Romualdo
}

\section{REFERENCES}

Martinon, Jean-Paul. ed. 2013. The Curatorial: A Philosophy of Curating. London:

Bloomsbury. 280 pages, ISBN: 978-1-4725-2560-4.

1 In the words of Jean-Paul Martinon, this book's editor, The Curatorial: A Philosophy of Curating originated from a "wish to talk about curating", the same wish that led to the creation, in 2006, of a practice-led PhD programme at Goldsmiths College, called Curatorial/Knowledge. The anthology features contributions from tutors, guest speakers and students, all of whom delve into what "the curatorial" is and what it might mean in the future. Curating, or the act of organizing exhibitions, parallel events, and all that those activities entail, is treated as an insufficient starting point hence the book's slogan: "Stop curating! And think what curating is all about".

If 'curating' is a gamut of professional practices that had to do with setting up exhibitions and other modes of display, then 'the curatorial' operates at a very different level: it explores all that takes place on the stage set-up, both intentionally and unintentionally, by the curator, and views it as an event of knowledge. So to drive home a distinction between 'curating' and 'the curatorial' means to emphasize a shift from the staging of the event to the actual event itself: its enactment, dramatization and performance. (Preface by Jean-Paul Martinon and Irit Rogoff, p. ix)

2 The curatorial can thus be roughly defined as the creation of knowledge within this field that happens on the edge of the activities usually associated with curating. More concerned with reflexivity than with a final product (exhibition or something else) or methodologies of work, it does not, however, seek to defend that theory/thinking are more important than practice/doing. Rather, it seeks to obliterate the distinctions 
between thinking and doing, to explore the possibilities hidden beyond the limits of the field.

3 The book's focus on the 'curatorial', as opposed to curating or exhibition-making, may lead readers to think that these discussions are happening outside (and independently of) the places where art is produced, exhibited and discussed. However, this book starts from an expanded notion of what those spaces are and what they might become, exploring the production of knowledge in a philosophical sense and feeding back the arguments and hypotheses into a (possibly) transformed field of practice.

What does this mean for contemporary curating? Are the sites of traditional exhibitionmaking - museums, galleries, fairs, biennials, conferences, workshops, repurposed spaces - not enough for a field that has started to reach a maturity and self-reflexivity that it was previously lacking? Have they become too problematic and self-contained to continue to function as sites for production of meaning? Does the curatorial need to find new spaces - be it cinematic, imaginary, transient or choreographic - or does it simply need new models of thinking in order to tap into hidden potentials within familiar spaces?

5 Interestingly, many of the authors approach the curatorial from a perspective only tangentially related to what can be considered the "traditional" role of the curator. From setting aside computers and looking at old newspapers as an act of foreseeing the future (Alfredo Camerotti), to looking at the connections between radio and exhibitions (Jean-Louis Déotte), to studying the possibilities of cinema as a space for curating memory (Cihat Arinç), the contributions within this book range from the metaphorical, to the philosophical, to the practical, always grounded by a commitment to theoretical discussion. Irit Rogoff looks at the expansion of the field of curating as paradoxically constraining, and proposes how to go beyond those constraints, while Suzana Milevska questions the assumptions behind the curator's role, and uses Deleuze's understanding of the word "becoming" in order to distinguish between the professional decision to become a curator and the process of "becoming-curator" (p. 67).

6 A sense of uneasiness and uncertainty about what the curatorial means, and what a curatorial practice entails, permeates most of the texts. Many attempts are made to answer the questions put forward while thinking about the curatorial: what is the relationship between the curatorial and other disciplines? What kind of languages can and should we use while speaking of the curatorial? What connections can we find between exhibitions and the concepts of space, time and body? How can the curatorial question hegemonic structures of power? And, finally, what is the relationship of the curatorial to a curator's work, and how can we bridge the aforementioned gap between thinking and doing? This question is perhaps more noticeable on the book's last text, contributed by Charles Esche. In a decidedly darker tone than can be found throughout the rest of the book, Esche remarks on the impossibility of putting the curatorial into practice without falling into the traps inherent in curating:

[Curatorial practice] is a parasitical activity in the end, where the ability to manage, negotiate and compromise is generally the most prized of assets. A clever curator has constantly to trim and modify to try to ensure that something approximating a curatorial vision remains visible through the tangle of financial and other interests that shape the ground rules of a given project. (...) maybe it's better to say that [the curatorial] has aspirations to philosophical or aesthetic coherence but is so often compromised by the expectations of patrons and bureaucracies that the agency of the curatorial is rarely fully deployed. (Coda: The Curatorial by Charles Esche, p. 241) 
7 In a world with dwindling resources for art and, consequently, an increasingly difficult place for the survival of all the people and institutions implicated in it, Esche's text rings true. And for those in the field who come searching for guidance, this book may raise more doubts and questions than offer explanations or solutions. In the end, the disillusion makes the discussion on the curatorial all the more urgent. If the practice of curating is stifled and bound by a multitude of outside forces, then it is by discussing the curatorial that an alternative path can be forged. The multiplicity of perspectives included in this book can be considered a useful addition and potential starting points to this discussion.

\section{AUTHORS}

SOFIA ROMUALDO

Phd candidate, University of Exeter, United Kingdom, auralis@gmail.com 